\title{
Solution to the Bavarois challenge
}

\section{Hervé This}

Published online: 2 May 2012

(C) Springer-Verlag 2012

The winner of the Bavarois challenge (published in issue 402/7) is:

Lucia D'Ulivo, Ottawa, Canada

The award entitles the winner to select a Springer book of her choice up to a value of $€ 75$,-.

Our Congratulations!

\section{Solution}

Indeed, cooks know well that it is difficult to make pineapple bavarois; figs, papaya, kiwi fruits and some other fruits lead to similar failures [1]. Biochemists understand why: such fruits contain protein-hydrolyzing enzymes, for example bromelin, papain, or ficin [2]. In raw fruits these enzymes, when they are not inactivated by thermal treatment, degrade gelatin [3]. More precisely, gelatin molecules are polymers made primarily of repeating glycine, proline, and hydroxyproline amino acid residues (hydroxyproline is, in fact, found mostly in gelatin, and its presence is often used as a marker of gelatin) [4]. In collagen, three protein strands form triple helices because of the various forces, i.e. primarily hydrogen bonds and steric repulsion [5]. Of course, such a structure is only a good model, and many interesting chemical details could be given another time. Here let us restrict ourselves to saying that the strands

This article is the solution to the Analytical Challenge to be found at http://dx.doi.org/10.1007/s00216-011-5602-2

\section{H. This $(\bowtie)$}

INRA/AgroParisTech, UMR 1145,

Group of Molecular Gastronomy,

16 rue Claude Bernard,

75005 Paris, France

e-mail: herve.this@paris.inra.fr become separated when gelatin is dissolved in water at temperatures higher than $36^{\circ} \mathrm{C}$, but the separated strands try to re-coil when the solution is cooled; strands link by their ends, and form a network trapping water and other compounds. The $36{ }^{\circ} \mathrm{C}$ temperature explains why gelatin gels have the ability to melt in the mouth when the temperature is higher than the melting point of gelatin (at least for some kinds of gelatin), but not at room temperature. Of course, a gel can be formed only at concentrations higher than the percolation threshold $[3,6]$.

With regard to proteases, one can observe their action in the following experiment: make a gelatin gel, and when it is set, dip into it a piece of a slice of fresh pineapple. The gel will turn back into a liquid! And how is it possible to obtain a Bavarois from figs, papaya, or pineapple? Simply boil the fruit purée, because the gelatin-degrading proteases are not heat resistant.

\section{References}

1. Larousse gastronomique (2010) Editions Larousse, Paris

2. Vanderghem C, Francis F, Danthine S, Deroanne C, Paquot M, de Pauw E, Blecker C (2011) Study on the susceptibility of the bovine milk fat globule membrane proteins to enzymatic hydrolysis and organization of some of the proteins. Int Dairy J 21:312318

3. Djabourov M, Leblond J, Papon P (1988) Gelation of aqueous gelatin solutions I. Structural investigation. J Phys France 49:319-332

4. Ayas S, Boot-Handford RP, Humphries MJ, Kadler KE (1998) The extracellular matrix fact books, 2nd edn. Academic Press, San Diego

5. Ottani V, Martin D, Franchi N, Ruggeri A, Raspanti M (2002) Hierarchical structures in fibrillar collagens. Micron 33:587596

6. de Gennes PG (1979) Scaling concepts in polymer physics. Cornell University Press, New York 